\title{
Conceptualization Of Public Service Model on City Government
}

\author{
Dasman Lanin ${ }^{1}$ and M. Fachri Adnan ${ }^{2}$ \\ ${ }^{1}$ Professor of Public Management, Department of Public Administration Science \\ Faculty of Social Science, Padang State University, \\ dasmanlanin@gmail.com \\ ${ }^{2}$ Senior Lecturer at Department of Public Administration Science \\ Faculty of Social Science, Padang State University, \\ fachri.adnan@gmail.com
}

\begin{abstract}
The purpose of this paper is to publish the findings of research that has spawned an academic concept of public service that is able to increase public satisfaction with local government services. The research uses quantitative methods and statistical analysis. Data were collected through questionnaires that were valid and reliable. The sample was drawn from the stratified proportional random sampling. This process wish to test a model that was constructed based on a variety of models as reviewed from various scientific journals and the results of the research that has been done before. Finally, it was found that there are seven independent variables were able to significantly improve people's satisfaction in public service held by government. In other words, this research found that hypothetical model has been tested on a limited basis in the city government. All variables constructed in the model can be used to form the model, but this model still requires testing the validity of the spectrum of types of services are varied and diverse characteristics of the area, in hopes of finding a stable model structure and universally valued.
\end{abstract}

Keywords : Public Service Model, Public Satisfaction, City Government

\section{Rationale and Method}

Objective conditions of public services provided by local governments are still far from the minimum standard, even excellent services. While public service is a public right that must be fulfilled by a state (Kurniawan \& Puspitosari, 2007). Almost all of previous research showed that Indonesian bureaucracy has disorientation disease. In the civil service, it is easily visible behavioral symptoms such as asking to be served in the form of bribes. In Kediri and Surabaya, there are $55.4 \%$ and $52.4 \%$ of imbalanced behavior. (Kurniawan \& Puspitosari, 2007). Based on his research, Afadlal (2003) concluded that the bad service of municipality was a result of disorientation of fundamental function of local government as a provider of public services. Meanwhile, the substantive public service is the service that able to produce customer satisfaction in the performance of the basic functions and the government's responsibilities. This study was very urgent to find a new model of government service to satisfy the community and the basic concept of
Public Satisfaction factor. This would be able to contribute to the development of public service management. This study was intended to go into the main-stream of the academic development.

This study was based on expert opinion of the satisfactory provision of service for society and the factors that will determine the satisfaction of creation, both theoretical and research findings. Various findings and expert opinion of this research was integrated in the explanation of the results of this study. So the literature reviews in this article service as descriptors, amplifier and fortitude for the finding of this study. The method used is quantitative research in order to examine the hypothetical compiled frame (constructed) based on the synthesis of previous expert findings. Based on the above analysis of each of the independent variables ( 7 variables) and multiple regression, the basic construction of the research model can be described as figure 1. 


\section{Research Findings}

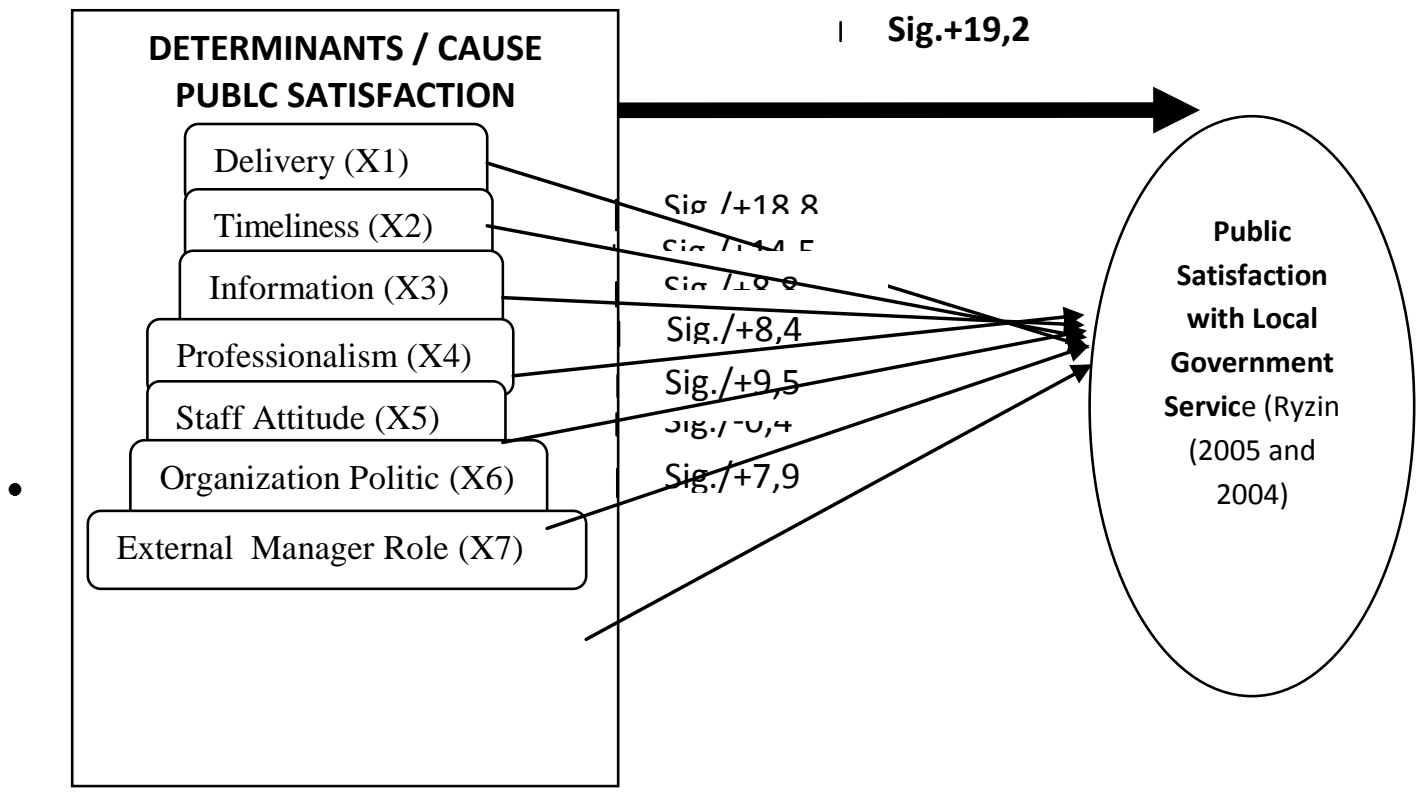

Figure 1:Construction of the Satisfactory Model of Public Service (Dasman Lanin, 2013)

\section{Discussion}

Based on the model, it turns out that each of the variables that affect people's satisfaction has a different contribution. Delivery is the main variable in the model.

\subsection{Delivery and Public Satisfaction}

Delivery was a significant variable that positively influenced for Public Satisfaction and its contribution is around $18.8 \%$. These findings reinforce the findings of Thomson and Mori (2004) that found the effect of 30\%, and Froehle (2006) that found $35.9 \%$ of the contribution. The difference is probably due to the contribution of delivery of different indicators. This study uses indicators:1) the final outcome, 2) the way the service kept its promises, 3) the way the service handled, and 4) significant commitment beyond oneself. While Thomson and Mori uses only the first three indicators. Brown (2007), Froehle (2006) and Perry and Thomson (2006) also supports a significant relationship proficiency level. So the delivery is a very important deciding factors considered in view of its influence, while also deserve to be the main element in reconstructing the model. 
Table 1. Ranking of Independent Variables Influences

\begin{tabular}{|l|l|l|l|r|}
\hline \multicolumn{1}{|c|}{ No } & Independent Variabel (X) & Dependent Variable (Y) & Sig. & R \\
\hline 1. & Delivery (X1) & Public Satisfaction & $* /+$ & $18,8 \%$ \\
\hline 2. & Timeliness (X2) & Public Satisfaction & $* /+$ & $14,5 \%$ \\
\hline 3. & Staff Attitude (X5) & Public Satisfaction & $* /+$ & $9,5 \%$ \\
\hline 4. & Information(X3) & Public Satisfaction & $* /+$ & $8,8 \%$ \\
\hline 5. & Professionalism (X4) & Public Satisfaction & $* /+$ & $8,4 \%$ \\
\hline 6. & External Manager Role (X7) & Public Satisfaction & $* /+$ & $7,9 \%$ \\
\hline 7. & Organization Politic (X6) & Public Satisfaction & $* * /-$ & $0,4 \%$ \\
\hline
\end{tabular}

Notes: $*=$ Sig. $1 \% ; * *=$ Sig. $5 \% ; \mathrm{R}=$ contribution

\subsection{Timeliness and Public Satisfaction}

Timeliness and Public Satisfaction in this study showed positive significant influence and the contribution is around $14.5 \%$. This variable can also be an important element in shaping a satisfactory model of public service. This finding also confirms the findings of Thomson and Mori (2004) and Perry and Thomson (2006) who concluded that the variables correlated with public satisfaction in local government in the UK, and contributes is around $24 \%$. The indicators are: initial wait, how long it takes overalls, number of times had to contact the service. Thus it can be believed that this variable also deserves to be a decisive variable in the model reconstruction.

\subsection{Staff Attitude and Public Satisfaction}

The effect of staff attitude in public service is positively significant influenced towards public satisfaction. This variable is defined by the indicator: 1) polite and friendly staff, 2) how sympathetic staff were to your needs, 3) as impartial and honest, just bureaucrat, 4) equal and fair, 5) deviations from good moral norms are rare, 6) adaptive and strategic bureaucrat, and 7 ) moralist and virtuous bureaucrat.
The seven indicators have contributions as $9.5 \%$. Previous findings also found by Thomson and Mori (2004) with a contribution of $12 \%$, with a fewer the indicators used in their study, that is: 1) polite and friendly staff, and 2 ) how sympathetic staff were to your needs. The influence of these variables is also supported by Dabholkar (1993), Froechle (2006), Lin, et al (2001), Kettinger \& Lee (2005), O'Kelly and Dubnick (2005) and in depth Vigado - Gadot (2006) refer to this variable as an Ethics variable with indicators of: 1) as impartial and honest, just bureaucrat, 2) equal and fair, and 3 ) deviations from good moral norms are rare. These three variables have contributions of $35 \%$. Thus it can be believed that this variable includes elements that can be accounted for academically outstanding public service model.

\subsection{Information and Public Satisfaction}

Information was significantly influenced towards public satisfaction with the services of the city government. These findings reinforce the results of previous studies, such as those found by Bass (1992) that the accuracy of information, actual, and relevance can increase satisfaction and even maturity 
for the recipient, and Mintzberg (1988) have called it as information power. In the model of Thomson and Mori (2004) have found a positive relationship to the level of information of high significance to the public satisfaction of with the contribution of $18 \%$. Thomson and Mori have used three indicators for these variables, namely: 1) accuracy, 2) comprehensiveness, 3 ) being kept informed about the progress. This variable was significantly positive affected on public satisfaction with public services organized by the local government and the contribution is around $18 \%$ and this study found $8.8 \%$ of the contribution, by adding the indicators of actual and relevance. So it can be believed that the information could be an element in conceptualizing a satisfactory model of public service in the city government.

\subsection{Professionalism and Public Satisfaction}

As an independent variable, professionalism has been shown to be a positive significant affect on public satisfaction with public services organized by the city government. Professionalism in this study is defined operationally by the indicators: 1) Competent staff, 2) being treated fairly, 3) knowledgeable employees are better trained, up-to-date, and educated with respect to the details of their functions and their firms' products and services and the contribution is around $8.4 \%$. This finding is supported by Froehle (2006) which states that the service provider's ability to perform adequately has been shown to have a positive significant influence on the public satisfaction in public service with the contribution of $20 \%$. Thomson and Mori (2004) also found that professionalism has significantly positive affected on public satisfaction with local governments and the contribution is about $16 \%$, although with a different indicator of Froehle, where Thomson and Mori using indicators; 1) competent staff and 2) being treated fairly. Mintzberg (1988) calls this variable in terms of expertise. George (1991) supports the influence of this variable. Thus, the results of this study can reinforce the evidence that professionalism really affected the public satisfaction and it is a component that needs to be involved in constructing a model.

\subsection{External Manager Role and Public Satisfaction}

The findings of this research note that the external manager role has significant positive effect on public satisfaction with public services organized by city government. The independent variable is defined by the indicator; 1) The role of symbolic, 2) The role of liaison, 3) The role of monitoring , 4) The role of spokesman, 5) The role of entrepreneurs , and 6) The role of negotiator. All of these indicators function as a variable content of external Manager Role that has significant positive effect on public satisfaction. The contribution was found to be $7.9 \%$. This is supported by Mintzberg (1988) "The societal shift toward greater democracy will cause the original manager to spend more time in the leader role". Dasman Lanin (2007) has found considerable contribution around $7.5 \%$ and Dasman Lanin (2008) concluded that "As for the external role of the manager constructs used Mintzberg's Theory and the construct of citizen satisfaction used the Expectancy Disconfirmation Model Citizen Satisfaction Local Government of Ryzin \& Gregg, its result Showed correlation which was significant". The theory of Mintzberg (1988) has explored this variable seriously, and this role is widely used by other experts in explaining the issue of manager. Indeed, it is a variable worthy of a buffer for the formation of a satisfactory model of public service.

3.7. Internal Politics of the Organization and Public Satisfaction 
As an independent variable in this study, Internal politics of the Organization has been shown to have a significant negative effect on public satisfaction and the contribution is $-0.4 \%$. Indicators used for this variable are; 1) the purposes of only a few individuals, 2) Favoritism, 3) affected by Political pressures, 4) Clickclandestine competition, 5) Deviations interests of the organization (deviation ), and 6) Unclear division of tasks. This finding reinforced the previous findings by Minztberg (1988), DuBrin (1990), and by Yusof (2001:11). Vigoda-Gadot findings (2006) have also proved the same thing. He found that there was a significant negative correlation between organizational politics with public satisfaction with a contribution of 19\%. This is supported by research of Dasman Lanin (2010) concluded that "Theoretically, organization external politics factors can be used as predictors to Determine citizen satisfaction of local government service". Thus the organizational politic variable could be as a portion of the construction that is satisfactory model of public services at the local government.

\section{Conclusion}

This study has found a hypothetical model with seven independent variables, which have partial or simultaneous significant impact on public satisfaction with public services in the city government. This model has been confirmed by the findings of many experts.

\section{References}

(1) Afadlal. (2003). Dinamika Birokrasi Lokal Era Otonomi Daerah. Jakarta:LIPI

(2) Bass, M, B. (1992). Handbook of Leadership: Theory, Research and Managerial Aplications. New York: A Division of Mc Millan, Inc.
(3) Brown, T. (2007). Coersion versus Choice: Citizen Evaluations of Public Srvice Quality across Methods of Consumtion, Public Administration Review, May|June 2007

(4) Dasman Lanin (2013). Konseptualisasi Pelayanan Publik yang Memuasakan Masyarakat pada Pemerintah Daerah, Padang: Lemlit UNP

(5) -------------(2007). Pengaruh Peranan Manajer terhdp Kepuasan Warga dg Pelayanan Pemda, FIS UNP

(6) ----------- (2008). Influencing Manager Roles toward Incresing Public Servece on Local Government, The International Conference on Islamic Studies and Muslim Studies, Prince of Songkla University (PSU), Pattani Campus, Southern Thailand $18^{\text {th }}$ August 2008.

(7) (2010). The Effects of BureuaucracyInternal Politics towards Citizen Satisfaction, Journal of Administrative Sciences \& Organization, Bisnis \& Birokrasi, Vol 17, Number 3, Nov. 2010.

(8) (2012). Citizen Satisfaction with Local Government,International Conference of Public Organization(ICONPO), Korea University, Seoul, Korea Mey 11, 2012

(9) Froehle, C. M. (2006). Service Personnel, Technology, and Their Interaction in Influencing Customer Satisfaction, Decision Sciences, volume 37 Number 1, February 2006

(10) Kurniawan, J, L \& Puspitosari, H. (2007). Wajah Buram Pelayanan Publik. Malang: YAPPIKA

(11) Mintzberg, H. (1988). Power in and Around Organization. New Jersey USA: Prentice-Hall, Inc.

(12) O’Kelly, C., \& Dubnick, M. J. (2005). Taking Tough Choices Seriously: Public Administration 
and Individual Moral Agency, Journal of PART, Volume 16, Oxford University Press

(13) Perry, J, L \& Thomson, A, M,. (2006) Service with a Smile, Journal of Public Administrasion Research and Theory, 25 January 2006, Oxford University Press

(14) Ryzin, G, G, V, Muzzio, D, Immerwahr, S, Gulick, L, Martinezz, E,. (2004) Drivers and Consequences of Citizen Satisfaction: An Aplication of The American Customer Satisfaction Index Model to New York City, Public Administration Review, Volume 64 No.3

(15) Ryzin, G, G, V,. (2005) Testing The Expectancy Disconfirmation Model of Citizen Satisfaction with Local Goverment, Journal of Public
Administrasion Research and Theory, Volume 16

(16) Thomson, W \& Mori,. (2004) Costumer Satisfaction with Key Public Services, www.cabinetoffice.gov.uk/opsr

(17) Vigoda-Gadot, E,. (2006) Citizens' Perceptions of Politics and Ethics in Public Administration: A Five-Year National Study of Their Relationship to Satisfaction with Services, Trust in Governance, and Voice Orientations, Journal of PART, Volume 17, Oxford University Press

(18) Yusof, A, A,.(2001) Politik Organisasi dalam Penilaian Prestasi (Realiti atau persepsi), Sintok, UUM 